\title{
Translational signaling and systems biology
}

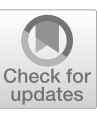

Marcello Maggiolini*

We are delighted to announce the launch of a new section in the Journal of Translational Medicine entitled "Translational signaling and systems biology".

Cells respond to a broad range of signals sensing transduction mechanisms that feedforward circuits involved in cell life and fate. Great progress has been recently made on how extracellular information are fine tuned into intracellular physiological and pathological outcomes. Regardless of skill to cross (i.e. steroids) or not to cross the cell membrane (i.e. growth factors), extracellular signals are transmitted to intracellular environment through a variety of transduction pathways and sensing cues. Noteworthy, innovative methods and technologies including imaging and nanotechnologies, molecular modelling, new algorithms of artificial intelligence, bioinformatics and systems biology, have better uncovered the actual role of transduction signaling on key cell fitness, from basic to translational research [1-4].

In addition, much attention has been paid on mechanotransduction that refers to the transmission of external mechanical forces to molecular sensors mediating intracellular changes. It is now clear that the complex apparatus harbored by cell membranes not only allows the trafficking of ions and molecules, but also acts as a smart structure in the mechanosensitive processes. For instance, conformational changes and signals originating from the ECM may lead to cell-matrix interactions in peculiar sites named focal adhesions. Then, multi-protein complexes connect extracellular space to the intracellular compartment and the cytoskeleton, turning the transmission of mechanical forces into biological features [5].

Overall, either potential opportunities or problems may be caused by messengers and factors shared by multiple

*Correspondence: marcello.maggiolini@unical.it

Department of Pharmacy and Health and Nutritional Sciences, University

of Calabria, via Bucci, 87036 Rende, Italy signaling pathways. In this regard, a fine cross-talk among diverse transduction cascades allows a superior regulation of cell activity respect to the action of individual pathways. On the contrary, deleterious cross talk induces certain pitfalls leading to altered biological information. In order to better appreciate this intricate landscape, it appears beneficial to scrutinize the multifaceted signal transduction network by systems biology approaches, which may strongly contribute to clarify how expected or inappropriate biological responses could occur through complex molecular interactions [6]. In this context, the first question is how to assess further causality considering pathways of whole cell by statistical correlation in large data sets. The second issue regards how to unveil novel mechanistic routes crossed by the cell machinery from a systems perspective. Next, modeling and simulation signal transduction systems would provide a unique opportunity to integrate in-vitro and in-vivo experimental data, thus allowing the evaluation of the dynamics that regulate huge molecular platforms. For instance, integrating the mode of action of drugs through dynamical data and a combination of players may be very useful toward the prediction of challenging targeted therapies.

Actually, the field is dynamic and exciting due to the chance to facilitate the translation of new therapeutic breakthroughs targeting dysregulated signaling pathways into clinical settings. Therefore, we are interested in research that investigates and characterizes translational signalling, even taking advantages of systems biology.

The Journal of Translational Medicine provides high standard peer-review process and represents a space for efficiently communicating up-to-date results and scientific discussions. The new section on "Translational signaling and systems biology" will guarantee high quality and competitive publications. The Editorial Board is looking forward to receiving your contributions. original author(s) and the source, provide a link to the Creative Commons licence, and indicate if changes were made. The images or other third party material in this article are included in the article's Creative Commons licence, unless indicated otherwise in a credit line to the material. If material is not included in the article's Creative Commons licence and your intended use is not permitted by statutory regulation or exceeds the permitted use, you will need to obtain permission directly from the copyright holder. To view a copy of this licence, visit http://creativecommons.org/licenses/by/4.0/. The Creative Commons Public Domain Dedication waiver (http://creativeco mmons.org/publicdomain/zero/1.0/) applies to the data made available in this article, unless otherwise stated in a credit line to the data. 


\section{Authors' contributions}

MM wrote the manuscript. The author read and approved the final manuscript.

\section{Declarations}

\section{Competing interests}

The Author declare that he has no competing interests.

Received: 26 October 2021 Accepted: 16 November 2021

Published online: 30 November 2021

\section{References}

1. Jamal S, Ali W, Nagpal P, Grover A, Grover S. Predicting phosphorylation sites using machine learning by integrating the sequence, structure, and functional information of proteins. J Transl Med. 2021;19(1):1-1.

2. Zhao Y, Zheng K, Guan B, Guo M, Song L, Gao J, Qu H, Wang Y, Shi D, Zhang Y. DLDTI: a learning-based framework for drug-target interaction identification using neural networks and network representation. J Transl Med. 2020;18(1):1-5.

3. Gao X, Cai Y, Wang Z, He W, Cao S, Xu R, Chen H. Estrogen receptors promote NSCLC progression by modulating the membrane receptor signaling network: a systems biology perspective. J Transl Med. 2019;17(1):1-5.

4. Phua QH, Han HA, Soh BS. Translational stem cell therapy: vascularized skin grafts in skin repair and regeneration. J Transl Med. 2021;19(1):1-1.

5. Hayward MK, Muncie JM, Weaver VM. Tissue mechanics in stem cell fate, development, and cancer. Dev Cell. 2021;56(13):1833-47. https://doi.org/ 10.1016/j.devcel.2021.05.011.

6. Zhang L, Fan M, Napolitano F, Gao X, XU Y, Li L. Transcriptomic analysis identifies organ-specific metastasis genes and pathways across different primary sites. J Transl Med. 2021;19(1):1-1.

\section{Publisher's Note}

Springer Nature remains neutral with regard to jurisdictional claims in published maps and institutional affiliations.
Ready to submit your research? Choose BMC and benefit from:

- fast, convenient online submission

- thorough peer review by experienced researchers in your field

- rapid publication on acceptance

- support for research data, including large and complex data types

- gold Open Access which fosters wider collaboration and increased citations

- maximum visibility for your research: over $100 \mathrm{M}$ website views per year

At BMC, research is always in progress.

Learn more biomedcentral.com/submissions 